\title{
Videography and discography
}

\section{Videography}

(DVDs and video sources used as sources of network data)

Büld, W. (1978) Punk in London, Salvation Films

Corbijn, A. (2008) Control, Momentum

Factory (2007) 'Manchester from Joy Division to Happy Mondays', BBC4

Broadcast 21 September

Letts, D. (2000) Westway to the World, 3DD

Letts, D. (2008) The Punk Rock Movie, Freemantle Media

Nice, J. (2006) Shadowplayers, LTMDVD

Rock Family Trees (1998) And God Created Manchester, BBC TV Broadcast 9 October

Savage, J. (2007) Joy Division, Hudson

Sex Pistols (2005) Live at the Longhorn, Mawa Film

Temple, J. (2003) The Filth and the Fury, Film4 Video

Temple, J. (2007) The Future Is Unwritten, Film4

White, M. (1980) Rude Boy, Salvation Films

Winterbottom, M. (2002) Twenty-Four Hour Party People, Revolution Films

Wood, E. (2005) Made in Sheffield, Slackjaw Film

\section{Discography}

\section{Singles and EPs}

Bauhaus (1979) 'Bela Lugosi's Dead', Small Wonder

Buzzcocks (1977) 'Spiral Scratch', New Hormones

Buzzcocks (1977) 'Orgasm Addict', United Artists

Cabaret Voltaire (1979) 'Nag, Nag, Nag', Rough Trade

Chelsea (1977) 'Right to Work', Step Forward

The Clash (1977) 'White Riot', CBS

The Damned (1976) 'New Rose', Stiff

The Desperate Bicycles (1977) 'Smokescreen/Handlebars', Refill 
The Desperate Bicycles (1978) 'The Medium Was Tedium', Refill

Joy Division (1978) 'An Ideal for Living', Enigma

Joy Division (1978) 'An Ideal for Living' (12-inch), Anonymous

Joy Division (1979) 'Transmission', Factory

Joy Division (1979) 'Love Will Tear Us Apart', Factory

Joy Division (1980) 'Atmosphere', Factory

Little Richard (1956) 'Rip It Up', Speciality

Orchestral Manoeuvres in the Dark (1979) 'Electricity', Factory

The Ruts (1979) 'Babylon's Burning', Virgin

Scritti Politti (1978) 'Skank Bloc Bologna', St Pancras

Sex Pistols (1976) 'Anarchy in the UK', EMI

Sex Pistols (1977) 'God Save the Queen', Virgin

Sex Pistols (1977) 'Pretty Vacant', Virgin

Various (1978) 'A Factory Sample', Factory

Various (1979) '1980: The First Fifteen Minutes', Neutron

LPS

The Clash (1977) The Clash, CBS

Durutti Column (1980) The Return of the Durutti Column, Factory

Iggy and the Stooges (1972) Raw Power, Columbia

Joy Division (1979) Unknown Pleasures, Factory

Joy Division (1980) Closer, Factor

King Crimson (1970) In the Wake of Poseidon, Islan

The Ramones (1976) The Ramones, Sire

The Slits (1979) Cut, Island

Patti Smith (1975) Horses, Arista

Various (1973) Nuggets, Elektra

Various (1978) Short Circuit: Live at the Electric Circus, Virgin

Various (1979) Street to Street - A Liverpool Album, Open Eye Records

Various (1980) A Bouquet of Steel, Aardvark

Various (1982) To the Shores of Lake Placid, Zoo

Yes (1973) Tales of Topographical Oceans, Atlantic

\section{Album tracks}

Echo and the Bunnymen (1982) 'Read It in Books', on To the Shores of Lake Placid, Zoo

Richard Hell and the Voidoids (1977) 'Blank Generation', on Blank Generation, Sire

Sex Pistols (1977) 'EMI', on Never Mind the Bollocks, Virgin

Sex Pistols (1979) 'God Save the Queen (Symphony)', on The Great Rock ' $n$ ' Roll Swindle, Virgin

The Teardrop Explodes (1980) 'Books', on Kilimanjaro, Fontana

Velvet Underground (1968) 'Sister Ray', on White Light/White Heat, Verve 